\title{
41. THE RELATIONSHIP BETWEEN THE "R2" SEISMIC REFLECTOR AND A ZONE OF ABUNDANT DETRITAL AND AUTHIGENIC SMECTITES, DEEP SEA DRILLING PROJECT HOLE 610, ROCKALL PLATEAU REGION, NORTH ATLANTIC ${ }^{1}$
}

\author{
James F. Dolan, Earth Sciences Board, University of California at Santa Cruz ${ }^{2}$
}

\begin{abstract}
In Hole 610 , seismic Reflector "R2" is caused by an abrupt increase in sediment sonic velocity at approximately the lower/middle Miocene boundary. This increase in sonic velocity results from a zone of well-developed massive smectite cement. Scanning electron microscope, Energy Dispersive System, and X-ray diffraction studies show that the massive cement has a morphology distinctly different from the common crystalline detrital smectite that occurs disseminated throughout the sediment. These studies also suggest that both forms of smectite have similar compositions.

A widespread northeast Atlantic hiatus at the lower/middle Miocene boundary suggests there was increased bottomcurrent activity during the early middle Miocene. This increased circulation probably led to the scouring and entrainment of Norwegian Sea smectite and volcanic ash and their subsequent deposition at Site 610. This ash later altered to form the smectite cement responsible for reflector "R2."
\end{abstract}

\section{INTRODUCTION}

The "R2" seismic reflector is one of several regionally extensive reflectors identified in the northeast Atlantic (Montadert et al., 1979-their "2" reflector, Miller and Tucholke, 1983). In the Rockall Plateau region (Fig. 1) this reflector is late early to early middle Miocene in age (Montadert et al., 1979; Miller and Tucholke, 1983). Reflector "R2" is generally associated with a hiatus in northeast Atlantic DSDP sites (Miller and Tucholke, 1983), leading Miller and Tucholke (1983) to suggest that an erosive bottom-water pulse may have occurred at the level of "R2" in late early to early middle Miocene time. DSDP Hole 610 is notable because drilling here recovered a complete sedimentary section from this interval.

Seismic surveys of Site 610 (Fig. 1) show that reflector "R2" is located at $0.75 \mathrm{~s}$ sub-bottom (two-way traveltime) at approximately the depth of Core 610-19 (Masson and Kidd, this volume). Seismic velocity increases substantially near the reflector from $2.25 \mathrm{~km} / \mathrm{s}$ at $605 \mathrm{~m}$ (Core $610-18$ ) to $2.9 \mathrm{~km} / \mathrm{s}$ at $670 \mathrm{~m}$ (Core 610-22), suggesting an abrupt increase in sediment lithification. This increase in lithification is also manifested in the drilling rate, which decreased markedly during drilling of Cores 610-19 through 610-23 (Site 610 report, Operations section, this volume).

\section{METHODS}

Seventeen samples from above, within, and below the well-lithified zone (Fig. 2) were examined with a Semco Nanolab scanning electron microscope (SEM). Samples were mounted on aluminum plugs with silver paint and coated with a gold-palladium alloy in a Polaron sputter coater. Qualitative chemical compositions were obtained with a Princeton Gamma-Tech System 4 Energy Dispersive System (EDS) at-

\footnotetext{
${ }^{1}$ Ruddiman, W. F., Kidd, R. B., Thomas, E., et al., Init, Repts, DSDP, 94: Washington (U.S. Govt. Printing Office).

2 Address: Earth Sciences Board, University of California at Santa Cruz, Santa Cruz, CA 95064 .
}

tached to the SEM. In addition, mineral compositions of selected airdried samples were obtained using a Norelco X-ray diffractometer (XRD). These samples were first treated with dilute acetic acid to remove the carbonate component and were then glycolated and run at a scan rate of $1^{\circ} 2 \theta / \mathrm{min}$. Clay mineral percentages were determined using the method of Hein et al. (1976). The percentage of mixed-layer clay minerals in these samples was calculated using the method described by Perry and Hower (1970). Several of the samples were run from 60 to $63^{\circ}$ at a scan rate of $1 / 4^{\circ} 2 \theta / \mathrm{min}$. to determine whether smectite present is dioctahedral or trioctahedral. In this paper smectite is used as a general term for a group of clays that includes montmorillonite and nontronite. The smectites studied contain some intermixed illite layers and are thus mixed-layer clay minerals.

\section{RESULTS}

\section{Lithology}

Lower and middle Miocene sedimentary rocks recovered from Hole 610 consist of pale green nannofossil and marly nannofossil chalk with common thin medium green laminae. Smear-slide descriptions and XRD analyses reveal that these laminae contain higher percentages of smectite, detrital quartz, and sponge spicules than the surrounding sediment. The carbonate content decreases markedly downhole, with carbonate-bomb and smear-slide values decreasing from 80 to $90 \%$ in Core 610-17 (550-559.8 m sub-bottom) to typical values of 60 to $70 \%$ in Core 610-19 through Sample 610-24,CC (636.6$694.2 \mathrm{~m}$ sub-bottom).

Changes in detrital clay mineral content and degree of cementation allow division of the lower and middle Miocene section into three zones (Fig. 2). Minor amounts of detrital clay minerals, an absence of volcanic glass, and relatively little clay-mineral cement characterize the lowest zone, which extends from the bottom of Hole 610 at $723 \mathrm{~m}$ to approximately $688.3 \mathrm{~m}$ sub-bottom. The overlying section (zone 2, Section 610-18-4 to Sample 610-23,CC; Fig. 4B-D) contains abundant, crystalline detrital clay minerals in addition to well-developed massive clay-mineral cement and trace amounts of volcanic glass. This zone corresponds to an increase in sediment 


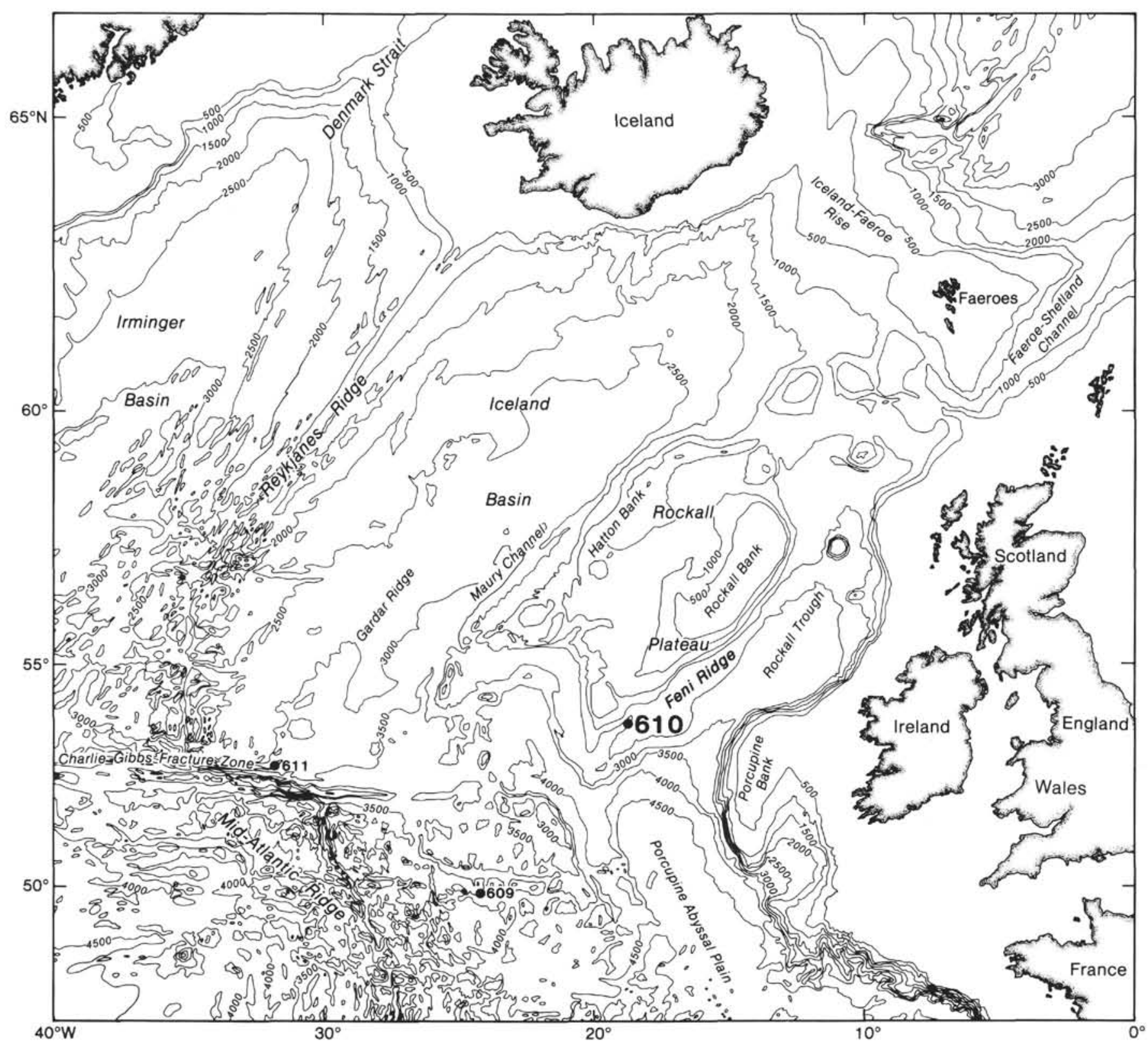

Figure 1. Location map of the Rockall Plateau region of the northeast Atlantic showing DSDP Site 610 (Leg 94).

sonic velocity and to Reflector "R2" (Fig. 2). Zone 1 (Core 610-16 to Section 610-18-4; Fig. 4A) is similar to zone 3 in that it contains relatively minor amounts of detrital clay minerals and no massive clay-mineral cement or volcanic glass.

\section{Clay Minerals}

Clay minerals are present in all samples but are much more abundant in samples from zone 2 than in samples from zones 1 and 3. SEM studies reveal that crystalline smectite dominates the clay-mineral assemblage in all three zones and that the smectite flakes are randomly disseminated through the predominantly carbonate sediment (e.g., Fig. 4A). The smectite flakes appear unattached or only weakly attached to surrounding sediment particles and probably did not grow in situ. This texture strongly suggests that most of the crystalline clay minerals in the Site 610 samples are detrital.

Qualitative EDS analyses of the clay minerals in bulk samples give spectra consisting of large subequal peaks of $\mathrm{Ca}$ and $\mathrm{Si}$ and a subordinate $\mathrm{Al}$ peak, with only minor amounts of $\mathrm{K}$ and $\mathrm{Mg}$. Fe was not detected. The strength of the Ca peak in these analyses may be in part caused by electron-beam excitation of nearby or underlying coccolith tests. However, the lack of any other significant element peaks suggests that $\mathrm{Ca}$ is the dominant cation in these clay minerals.

XRD analyses reveal that the clay-mineral assemblage typically consists of approximately $85 \%$ smectite (70$75 \%$ expandable layers), $7 \%$ chlorite-kaolinite, and $8 \%$ illite (e.g., Fig. 3). Slow-scan XRD analyses from 60 to $63^{\circ} 2 \theta$ show a strong single peak centered at approxi- 


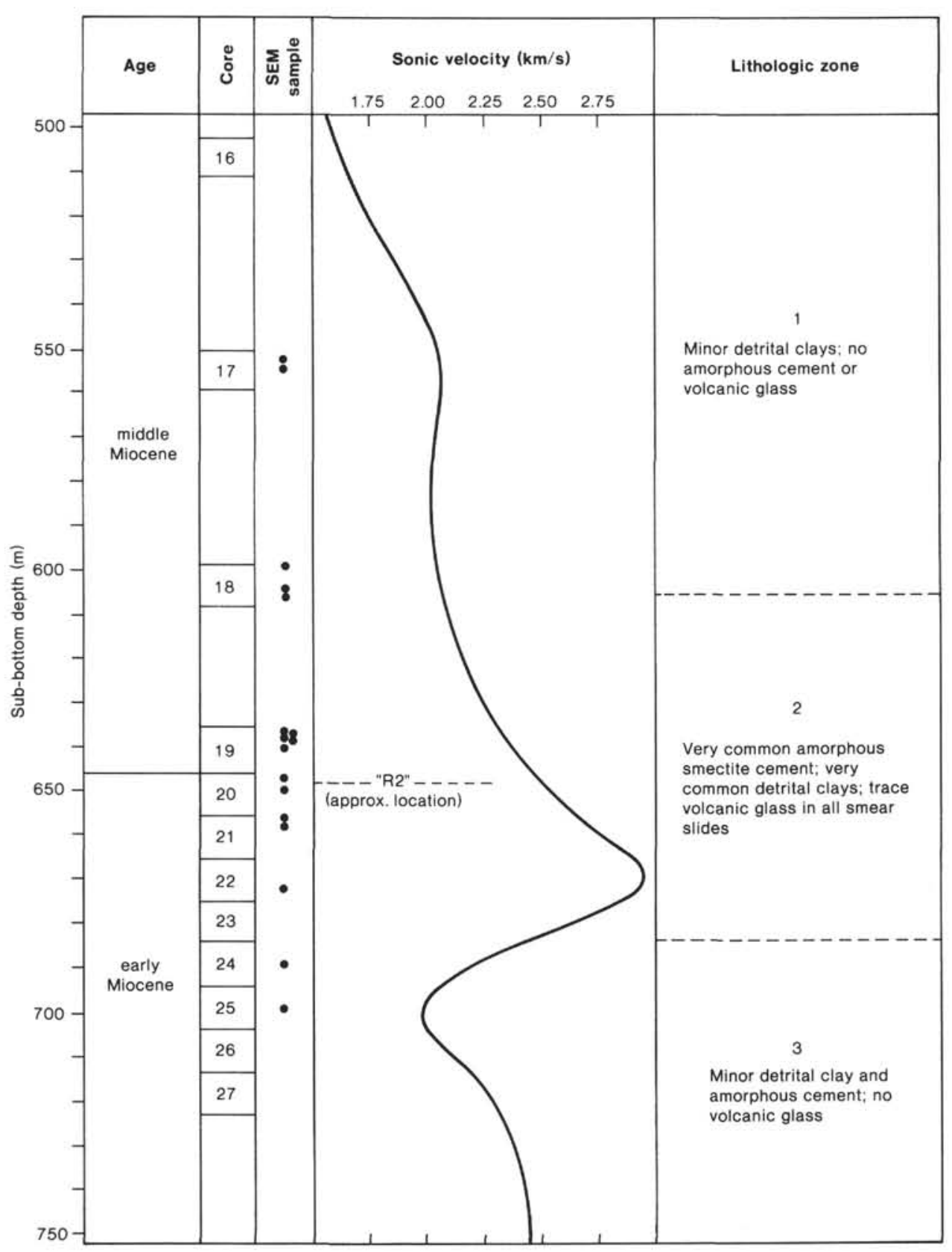

Figure 2. Correlation of lower-middle Miocene Site 610 cores, SEM sample locations, sonic velocity, lithologic zones, and the "R2" seismic reflector.

mately $61.8^{\circ} 2 \theta(2 \AA 1.502)$. This peak indicates that the smectite is dioctahedral montmorillonite. XRD scans from 3 to $13^{\circ}$ show a strong smectite peak at approximately $5.90^{\circ} 2 \theta(2 \AA 15.00)$ and consistent ancillary peaks at $19.90^{\circ} 2 \theta(2 \AA 4.47)$ and $17.95^{\circ} 2 \theta(2 \AA 5.0)$, suggesting a Ca-montmorillonite composition for the detrital smectite.

The minor amounts of chlorite-kaolinite and illite detected by XRD in these samples are probably detrital. This supports the textural evidence presented above for a predominantly detrital origin for the crystalline portion of the clay-mineral assemblage. However, SEM studies show that some of the crystalline smectite occurs as tightly intergrown masses of smectite flakes that appear to have an authigenic, pore-filling habit. Thus the crystalline clay-mineral assemblage in these samples probably consists of a combination of detrital (predominant; smectite, chlorite-kaolinite, illite) and authigenic (minor; smectite) clay minerals.

\section{Smectite Cement}

An abundant, massive mineral appears to be the dominant cement accounting for the increased lithification in zone 2 associated with increased sonic velocities and the "R2" seismic reflector (Fig. 2). EDS results show that this cement is a calcium aluminosilicate with peak strengths similar to those observed in the predominantly smectite detrital clay mineral assemblage. This 


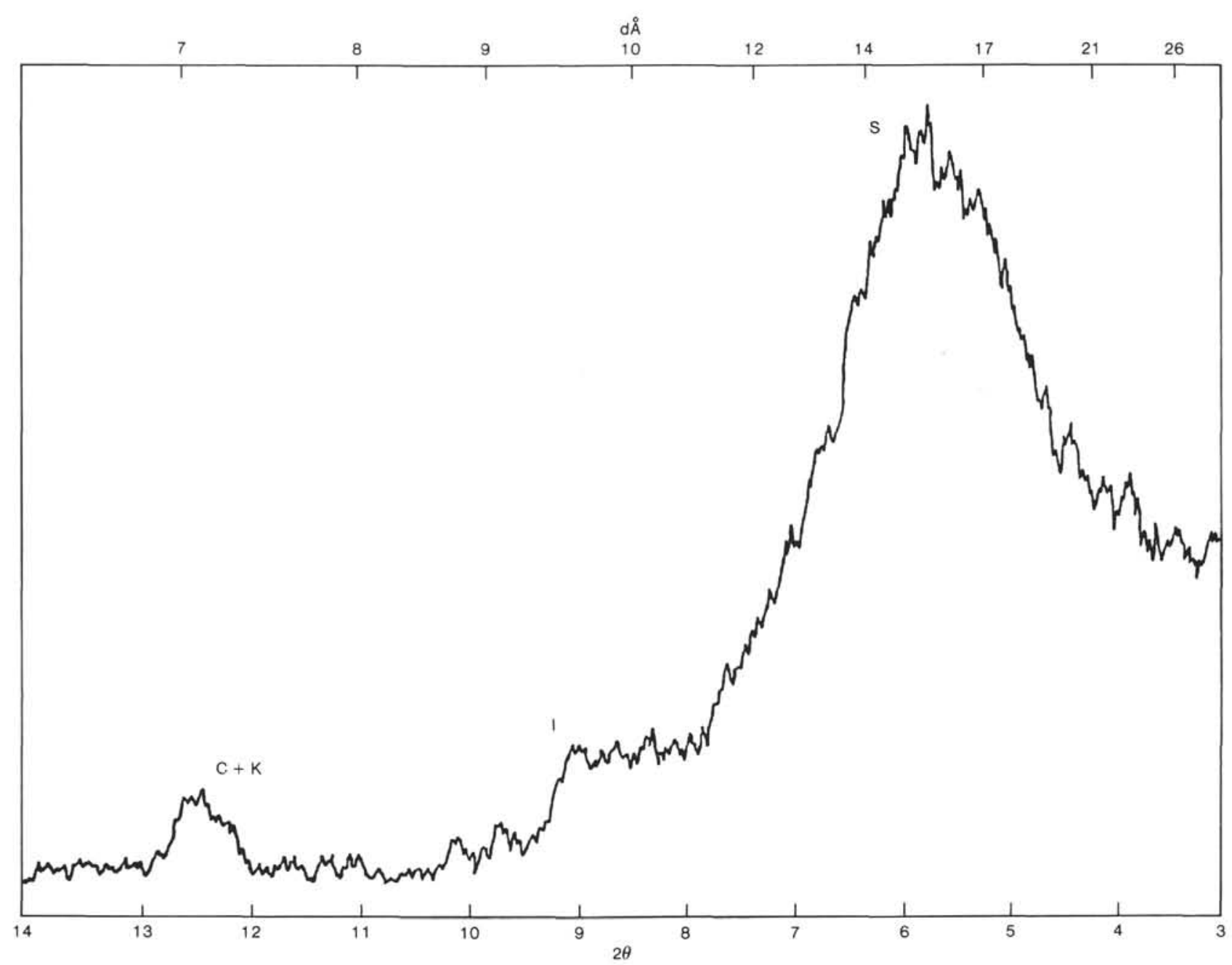

Figure 3. Typical X-ray diffractogram, kindly provided by J. R. Hein, of a glycolated, acetic acid-treated sample (610-20-2, 103-105 cm) from zone 2 . Note the predominance of smectite (S-85\% of sample) over illite $(\mathrm{I}-8 \%)$ and chlorite-kaolinite $(\mathrm{C}+\mathrm{K}-7 \%)$ in the clay-mineral suite. Smectite in this sample contains approximately $70 \%$ expandable layers.

compositional similarity suggests that the massive cement in zone 2 may be smectite with a growth habit distinctly different from the crystalline "webby" detrital smectite. SEM textural studies of the cement support this interpretation. Although the cement is generally massive, with no discernible crystal form, locally it grades into poorly crystalline authigenic smectite flakes (Fig. $4 \mathrm{D})$. In the best-developed examples, cement consists of crystalline smectite flakes oriented parallel to the surface of the cement.

Other possible silicate cements that might exhibit this massive habit include amorphous silica or poorly crystalline opal-CT, however, the expected XRD "hump" occurring between 18 and $30^{\circ} 2 \theta$ (Hein et al., 1978) was not observed.

\section{Zeolites}

A minor XRD peak at $22.8^{\circ} 2 \theta$ ( $2 \AA 3.90$ ) present in most samples from zone 2 may indicate the presence of clinoptilolite. However, the expected ancillary XRD peak at $9.8^{\circ} 2 \theta(2 \AA 9.02)$ is either absent or only weakly developed in these samples. In addition, no crystalline zeolites were observed with the SEM. These results suggest that if clinoptilolite is present, it is a minor constituent of the sediment.

\section{VOLCANIC SOURCE MATERIAL FOR THE SMECTITE}

Smectites are the dominant type of authigenic clay minerals formed during the alteration of volcanic glass (Kaestner, 1981). Hein and Scholl (1978) interpret claymineral assemblages that consist of more than $75 \%$ smectite as having a predominantly volcanic origin, based on their studies of clay mineralogy in DSDP cores from the southern Bering Sea. They also note that smectite containing high percentages of expandable layers formed authigenically in a marine environment as a result of the alteration of volcanic glass. A typical clay-mineral suite from zone 2 consists of $85 \%$ smectite with $\sim 70 \%$ expandable layers (Fig. 3) and thus supports the idea that both the detrital and authigenic smectites in zone 2 had a volcanic parent material. Minor fragments of volcanic glass and the possible presence of minor clinoptilolite also suggest a volcanic input. 

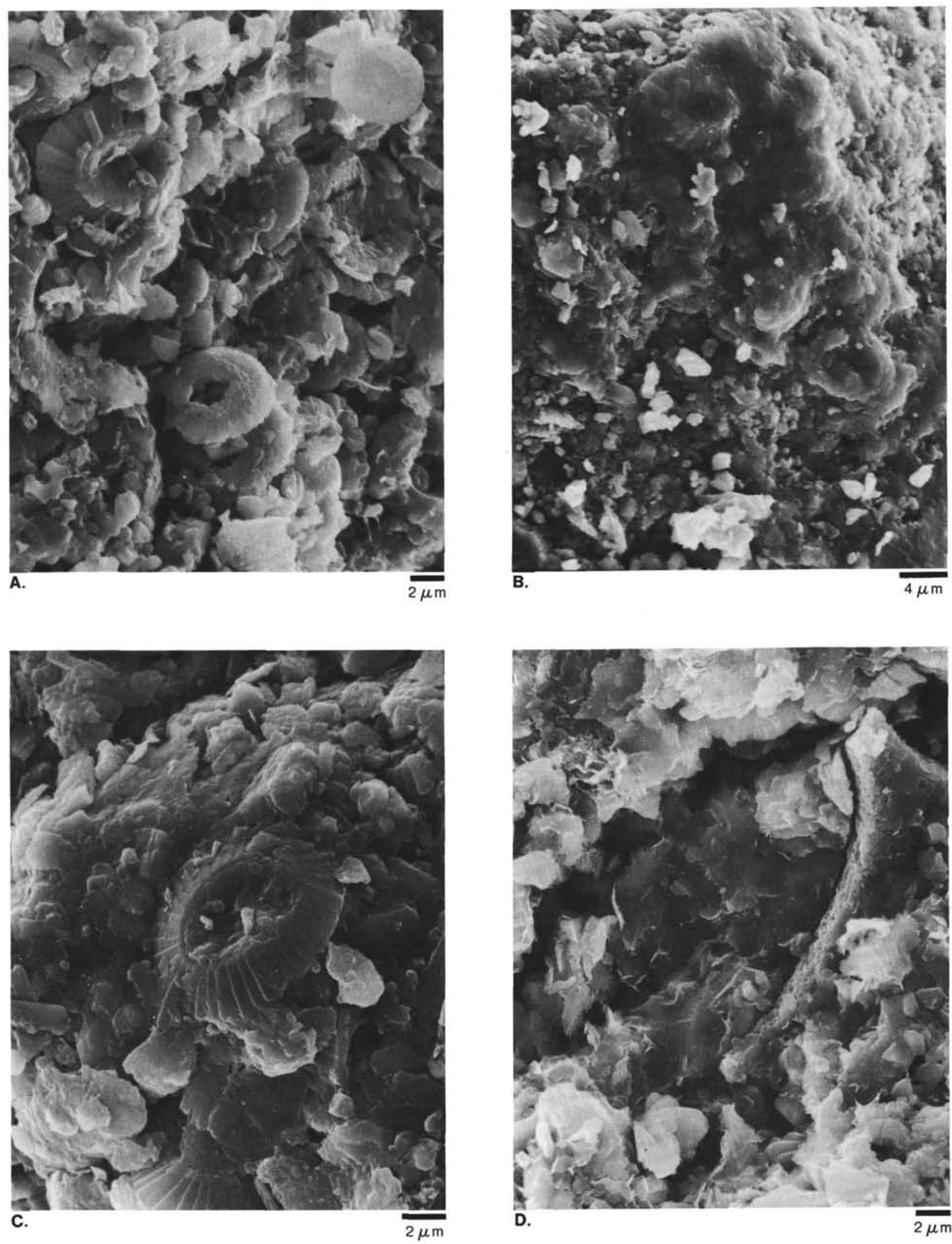

Figure 4. SEM photomicrograms of upper lower-lower middle Miocene sediments from Hole 610. A. View of sediment typical of zones 1 and 3; note open fabric, minor crystalline, detrital clays, and lack of massive cement (Sample 610-25-3, 119-123 cm, zone 3). B. Massive smectite cement from zone 2 (Sample 610-22-5, 26-31 cm). C. Close-up of massive smectite cement in zone 2; note local poorly developed platy habit, particularly near top of photomicrograph (Sample 610-18-4, 59-64 cm). D. Massive smectite cement grading into crystalline authigenic smectite (Sample 610-20-2, 104-106 cm). 


\section{PALEOCEANOGRAPHIC SIGNIFICANCE OF DETRITAL AND AUTHIGENIC SMECTITE}

A likely source of the abundant, crystalline smectite in zone 2 was Norwegian Sea sediment deposited in the Site 610 area by bottom-water currents. Similarly, the ash that altered to form the zone 2 smectite cement may have been redeposited Norwegian Sea sediment. Alternatively, this ash could have been deposited as primary ash fall from Icelandic eruptions during an early to middle Miocene increase in Icelandic explosive volcanism (Sigurdsson and Loebner, 1981).

A widespread hiatus at approximately the early/middle Miocene boundary indicates increased bottom-water circulation in the northeast Atlantic during this time interval (Montadert, Roberts et al., 1979; Berggren and Schnitker, 1983; Keller and Barron, 1983; Miller and Tucholke, 1983), possibly related to subsidence of the Iceland-Faeroe Ridge (Berggren and Schnitker, 1983). This increased circulation is also reflected at Site 610, where, although a continuous sedimentary sequence was recovered at the expected depth of the hiatus, sedimentation rates probably decrease from approximately $65 \mathrm{~m} / \mathrm{m}$.y. below Core 23 to $14.7 \mathrm{~m} / \mathrm{m}$.y. within well-cemented zone 2 (Cores 21-23; Site 610 report-Sediment accumulation rate section, this volume). This decrease probably represents alternate periods of scouring by bottom-water currents and sporadic deposition of Norwegian Sea sediments carried by the bottom water during slightly lower energy periods. These two regimes are probably separated by numerous, biostratigraphically unresolvable hiatuses within the "continuous" upper lower-lower middle Miocene section recovered at Site 610. The common occurrence of green laminae rich in smectite, detrital quartz, and sponge spicules that occur throughout this interval in Hole 610 may support this interpretation.

Additional evidence of probable changes in northeast Atlantic bottom-water circulation patterns is provided by changes in diatom preservation within the Hole 610 . The zone 2 smectite cement at reflector "R2" in Hole 610 corresponds to a zone of dissolution of biogenic silica, described by Baldauf (this volume); he notes a downhole decrease in diatom preservation in Hole 610, with moderate preservation in Core 16 giving way to poor preservation in Cores 17 to 21 and 23, and complete dissolution of the diatom assemblage in Core 22. Below this interval the diatom assemblage is characterized by the presence of abundant fragments of Ethmodiscus. Baldauf (this volume) notes that the dissolution may be related to increased flow of silica-undersaturated bottom water through the Rockall Plateau area during the late early and early middle Miocene. In addition, common concentrations of sponge spicules within zone 2 may reflect mechanical reworking consistent with increased bottom-current activity during this time interval. The anomalously abundant Ethmodiscus fragments noted by Baldauf to occur immediately below the poorly preserved interval may also indicate mechanical reworking and/or dissolution by bottom currents. Alternatively they may be the result of a "bloom" related to changes in surfacewater productivity (see Baldauf, this volume).

\section{CONCLUSIONS}

Reflector "R2" correlates with dramatic changes in physical properties in upper lower-lower middle Miocene sediments cored in DSDP Hole 610. Sediment sonic velocity increases markedly between Cores 610-17 and 610-23 as the result of clay-mineral cementation. The smectite composition of this cement and the possible presence of minor zeolites suggests that the cement formed as a result of in situ alteration of volcanic glass. Detrital smectite is common within the cemented interval and clearly indicates that at least part of the sediment has been redeposited. Poor preservation of biogenic silica in Cores $610-19$ through -23 and the presence of a widespread late early-early middle Miocene hiatus throughout the northeast Atlantic strongly suggest increased bottom-water circulation in the northeast Atlantic during this time interval. Thus both the detrital smectite in zone 2 and the ash that later altered to form the zone 2 smectite cement probably represent sediment redeposited at Site 610 at approximately the lower/middle Miocene boundary. A likely source of these sediments was the Norwegian Sea Basin, although a primary ash fall origin for the zone 2 ash cannot be ruled out.

\section{SUGGESTED RESEARCH}

Although the data discussed in this chapter do not necessarily document redeposition of Norwegian Sea sediments in the Rockall Plateau area during an increase in Norwegian Sea bottom-water outflow, they are consistent with this interpretation, and this hypothesis probably offers the most reasonable explanation. Further studies are needed to support the results of this preliminary study. In particular, more quantitative studies of the composition of the smectite need to be conducted. The results then must be compared with similar studies of potential parent materials from the Norwegian Sea. In addition, the distribution of the detrital smectite and the smectite cements needs to be better delineated, in order to reconstruct Norwegian Sea sediment dispersal patterns. This work may have to await future drilling in the northeast Atlantic. Finally, the coincidence of the detrital and authigenic smectites with the "R2" reflector has only been documented in Hole 610. Recent reevaluations of northeast Atlantic biostratigraphy with respect to the "R2" reflector (e.g., Miller and Tucholke, 1983) may allow more detailed correlation of bottom-current features (e.g., hiatuses, redeposited sediments) and the "R2" reflector.

\section{ACKNOWLEDGMENTS}

I would like to thank Jack Baldauf and Jim Hein, both at the U.S. Geological Survey, for their assistance throughout the preparation of this paper. Thanks also to Linda Anderson, Jim Boles, Mitchell Colgan, Bob Garrison, and Casey Moore for their helpful comments. Preparation of this manuscript was supported by NSF grant OCE-8315836 (J. C. Moore). Last but not least, thanks to everyone who participated in Leg 94 for an enjoyable and productive cruise.

\section{REFERENCES}

Berggren, W. A., and Schnitker, D., 1983. Cenozoic marine environments in the North Atlantic and Norwegian-Greenland Sea. In Bott, M. H., Saxov, S., Talwani, M., et al. (Eds.), The Structure and De- 
velopment of the Greenland-Scotland Ridge: New York and London (NATO Scientific Affairs Div., in cooperation with Plenum Press), pp. $495-548$.

Hein, J. R., and Scholl, D. W., 1978. Diagenesis and distribution of late Cenozoic volcanic sediments in the southern Bering Sea. Geol. Soc. Am. Bull., 89:197-210.

Hein, J. R., Scholl, D. W., and Gutmacher, C. E., 1976. Neogene clay minerals of the far northwest Pacific and southern Bering Sea: sedimentation and diagenesis. Proc. Int. Clay Conference, Mexico City, 1975., pp. 71-80.

Kaestner, M., 1981. Authigenic silicates in deep-sea sediments: formation and diagenesis. In Emiliani, C. (Ed.), The Ocean Lithosphere (Vol. 7): New York (Wiley and Sons).

Keller, G., and Barron, J. A., 1983. Paleoceanographic implications of deep-sea hiatuses. Geol. Soc. Am. Bull., 94:590-621.

Miller, K. G., and Tucholke, B. E., 1983. Development of Cenozoic abyssal circulation south of the Greenland-Scotland Ridge. In Bott,
M. H., Saxov, S., Talwani, M., et al. (Eds), The Structure and Development of the Greenland-Scotland Ridge: New Yort and London (NATO Scientific Affairs Div., in cooperation with Plenum Press), pp. 549-589.

Montadert, L., Roberts, D. G., et al., 1979. Init. Repts. DSDP, 48: Washington (U.S. Govt. Printing Office).

Perry, E., and Hower, J., 1970. Burial diagenesis in Gulf Coast pelitic sediments, Clays Clay Min., 18:165-177.

Sigurdsson, H., and Loebner, B., 1981. Deep sea record of explosive volcanism in the North Atlantic. In Self, S., and Sparks, R. S. (Eds.), Tephra Studies: Dordrecht, Holland, Boston, U.S. (NATO Scientific Affairs Div., in cooperation with Reidel Publ.), pp. 289-316.

Date of Initial Receipt: 14 January 1985

Date of Acceptance: 3 July 1985 